\title{
Gulf Coast Geology (GCG) Online
}

\section{http.//energy.cr.usgs.gov/oilgas/guilf/gcgonline}

A large percentage of the present and future energy resources of the United States resides in the Gulf of Mexico Basin, one of the major hydrocarbon-producing areas of the world. Recent conceptual and technological advances have resulted in important new discoveries and have led to new or renewed exploration in large areas of the basin. The U.S. Geological Survey's (USGS) Framework Studies and Assessment of the Gulf Coast Project was established in 1999 to conduct essential geologic, geophysical, and geochemical studies that will aid in a reassessment of energy commodities (coal, gas, and oil) in the Gulf Coast region. The project targets those stratigraphic intervals identified during previous oil, gas, and coal assessments as requiring additional study. Goals of the project are to (1) define the petroleum systems of the region; (2) conduct specific geologic framework studies and petroleum-system analyses on selected priority intervals; (3) study coal-bearing intervals to evaluate coal distribution and quality, coal-bed gas, and source-rock potential; (4) work in cooperation with the National Oil and Gas Assessment (NOGA) Project of the USGS to conduct a focused assessment of the Gulf Coast Region; and (5) contribute to the next phase of the USGS's National Coal Resource Assessment.
Gulf Coast Geology (GCG) Online is a Geographic Information System (GIS) database developed using map service technologies. It serves three primary needs of the project: (1) efficient, centralized data management and visualization; (2) development and sharing of data and interpretations by project personnel; and (3) dissemination of information and products to customers in a readily usable format. Currently, all USGS oil and gas assessments are petroleum-system based and require large amounts of geologic, geophysical, geochemical, and paleontologic data in addition to well and oil- and gas-field databases. In well-explored and developed regions and provinces, such as the Gulf Coast, these data sets can be

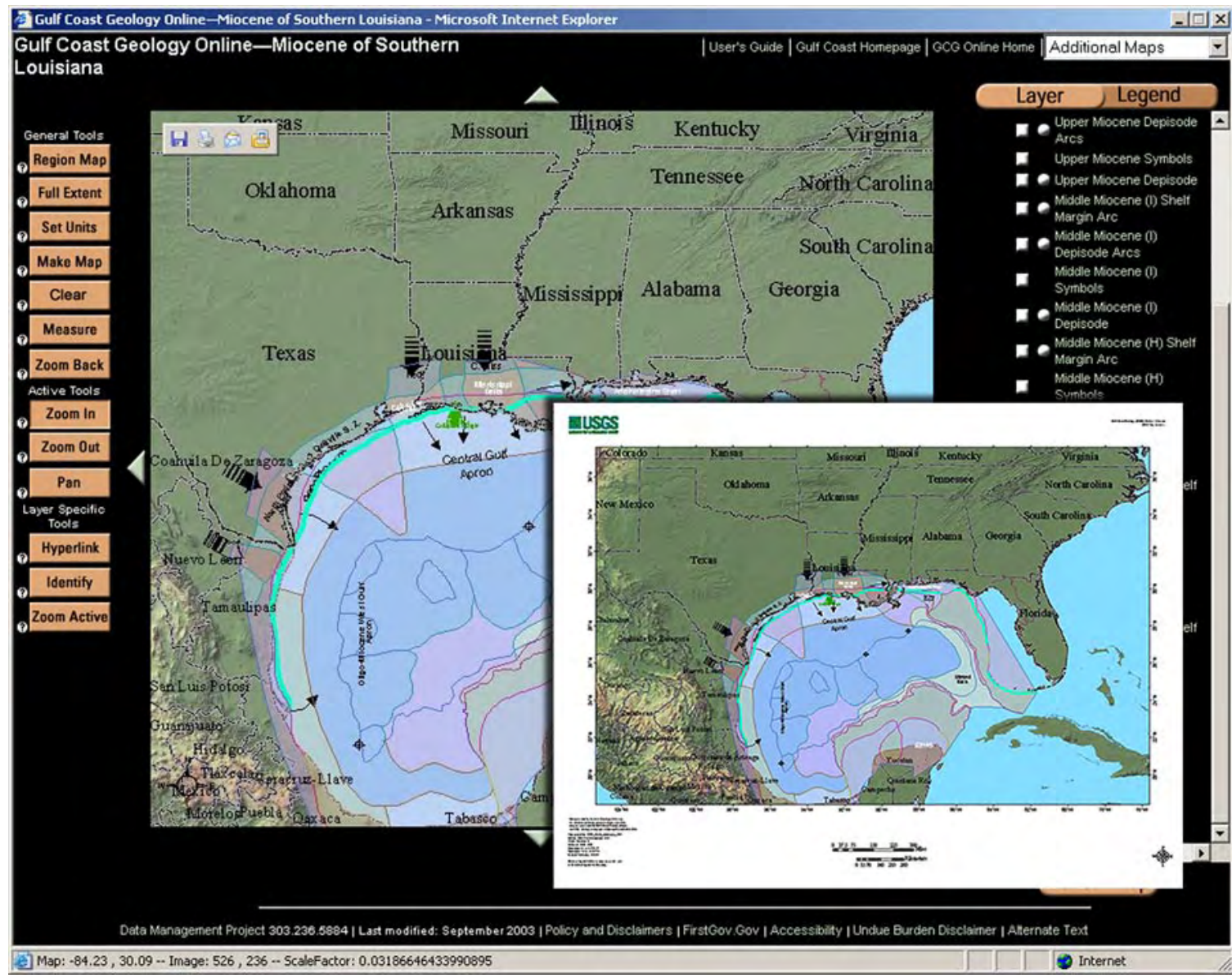

Figure 1. Example of GCG online Internet Mapping System and customized map output.

guses

栾竞

Internet 
large and require comprehensive data management. For example, the Miocene of southern Louisiana database alone currently consists of nearly 100 layers in addition to 25 layers of general geographic and geologic information. It is desirable for the large number of USGS project personnel working under tight deadlines on a wide variety of topics to have simultaneous and ready access to these data as well as to the data and interpretations most recently developed by other project scientists. An additional requirement is that the output be in a format that is easily used by project personnel or customers (such as administrators, other scientists, and the general public) who may or may not have GIS expertise or software. This requirement is particularly important for government agencies, such as the USGS, that place a strong emphasis on providing the best and most current information possible to decision makers and the public.

GCG Online is accessed via an Internet Mapping System (IMS) which can be used by anyone with an internet connection and web browser. The IMS allows users to interact with spatial information directly online in many ways. It has tools that can overlay the many different thematic layers, zoom in and out, make measurements, or perform basic que- ries by simply clicking on a feature of interest. Some advanced features include the ability to hyperlink directly to well information supplied by the State of Louisiana, and the ability to create custom, high-quality maps directly online for immediate download and for hardcopy printing (fig. 1).

The USGS will publish Data Series 90 (DS 90) in a series of releases that will be made available online as they are completed. DS 90-A will pertain to the Miocene only, whereas DS 90-B, 90-C, and so on, will pertain to other parts of the stratigraphic section. Each release will have a version number so that updates may be tracked and referenced.

DS 90-A, version 1.0, for example, deals almost exclusively with the Miocene of southern Louisiana. Sources of data specific to each individual layer within the database are documented in the metadata for that layer. In most cases, data from outside sources such as private industry are assumed to be sufficiently reliable for purposes of regional compilation, but the user is cautioned in the use of these data at prospect and smaller scales. All data are in the form of shapefiles and ArcSDE (Spatial Data Engine) layers that are maintained on the USGS Central Energy Resources Team (CERT) server along with the applications software. An

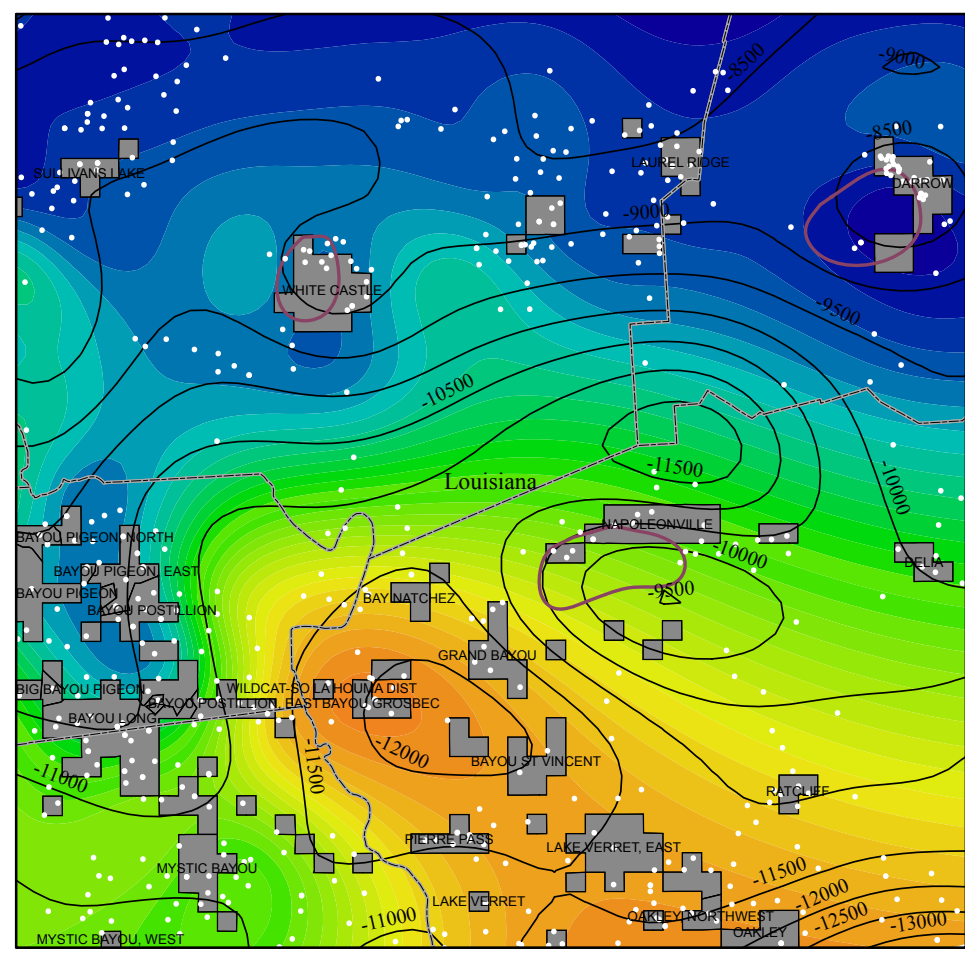

Figure 2. Example showing structure contours, control wells for structure contours (white diapers (areas enclosed by purple lines), and lower Miocene hydrocarbon producing areas (gray areas) overlain on isopach map (warm colors $=$ thicker) of lower Miocene of south-central Louisiana

\begin{tabular}{|c|}
\hline \\
\hline \multirow[t]{3}{*}{ لــــــــا 2 Mil } \\
\hline \\
\hline \\
\hline \\
\hline \\
\hline \\
\hline لــــــ \\
\hline
\end{tabular}
dots), salt updated version, DS 90-A, version 2.0, may combine data on the Miocene of Texas with the previously published data and will be published later. All versions of each release will be available through the CERT Web site.

Version 1.0 of the Miocene deals almost entirely with southern Louisiana, primarily because of the availability of data, especially biostratigraphic data. Publicly available data have been used wherever possible. However, in the case of proprietary data, such as the Tenroc Regional Geologic Database, only derivative products are made available. For example, the isopach and structure contour maps show the locations of wells used to construct the contours but do not reveal the precise depths of the micropaleontologic identifications in that well (fig. 2). In addition to the data specific to southern Louisiana, a number of regional geologic and geographic layers that will be applicable to all versions are included in version 1.0 for reference.

\section{For further information:}

\section{GCG Online is available at the USGS Central Energy Team Web site:} http://energy.cr.usgs.gov/oilgas/gulf/ gcgonline

\section{Geology:}

A. Curtis Huffman, Jr. achuffman@usgs.gov 303.236.1543

\section{GIS:}

Laura R.H. Biewick lbiewick@usgs.gov 303.236.7773

\section{Web Application: Gregory L. Gunther ggunther@usgs.gov 303.236.5884}

\author{
Acknowledgments: \\ Scott A. Kinney: GIS \\ Heather R. Mitchell: GIS \\ Chris C. Skinner: Database Management
}

